\title{
Analysis of musculoskeletal dysmorphic abnormalities of 20 fetuses
}

\author{
Yirmi fetüsün muskuloskeletal dismorfik anomalilerinin incelenmesi
}

\author{
Mehmet Nuri Konya, MD, ${ }^{1}$ Muhsin Elmas, MD, ${ }^{2}$ Çiğdem Özdemir, $\mathrm{MD}^{3}$ \\ ${ }^{1}$ Department of Orthopedics and Traumatology, Medical Faculty of Afyon Kocatepe University, Afyon, Turkey \\ ${ }^{2}$ Department of Medical Genetics, Medical Faculty of Afyon Kocatepe University, Afyon, Turkey \\ ${ }^{3}$ Department of Pathology, Medical Faculty of Afyon Kocatepe University, Afyon, Turkey
}

\section{ABSTRACT}

Objectives: This study aims to report rates of skeletal abnormalities and their risk factors in light of information obtained in a fetal autopsy series.

Patients and methods: The study included 20 fetuses (11 males, 8 females and 1 ambiguous genitalia; mean age $19.3 \pm 4.0$ weeks; range 16 to 32 week) who underwent autopsy in our hospital between January 2013 and March 2015. Fetuses were systematically classified according to age, gender, family history, abortus week, abortus type, and extremity and organ abnormalities. Skin biopsies were performed for genetic evaluation. Radiographic, pathologic and genetic findings were classified.

Results: Except one spontaneous abortus, all cases were applied medical abortus (94.1\%). Genetic diagnosis could not be established in seven cases, whereas genetic disorders were identified in 13 cases: two trisomy 13, two trisomy 18 , one (triploidi) 69,XXY, two arthrogryposis multiplex congenita, one osteogenesis imperfecta, one lethal multiple pterygium, one Saldino-Noonan syndrome, one teratogenic drug effect, one perinatal lethal hypophosphatasia, and one BeckwithWiedemann syndrome. Decreased fetal movement was one of the most frequently observed findings. Consanguineous marriage, oligohydramnios, drug addiction of the mother, teratogenic exposure, and other systemic abnormalities were risk factors.

Conclusion: Skeletal dysplasias are rare diseases. Clinicians should be careful for skeletal abnormalities in perinatal period follow-ups.

Keywords: Embryonic and fetal development; fetal death; fetal movement; genetic diseases; inborn.

\section{ÖZ}

Amaç: $\mathrm{Bu}$ çalışmada bir fetal otopsi serisinde elde edilen bilgiler ışığında iskelet anomali oranları ve bunların risk faktörleri bildirildi.

Hastalar ve yöntemler: Çalışmaya Ocak 2013 - Mart 2015 tarihleri arasında hastanemizde otopsi yapılan 20 fetüs (11 erkek, $8 \mathrm{k} 1 \mathrm{z}$ ve 1 belirsiz cinsiyet; ort. yaş 19,3 $\pm 4,0$ hafta; dağılım 16-32 hafta) dahil edildi. Fetüsler sistematik olarak yaş, cinsiyet, aile öyküsü, abortus haftası, abortus tipi, ekstremite ve organ anomalisi yönünden sınıflandırıldı. Genetik değerlendirme için cilt biyopsileri yapıldı. Radyolojk, patolojik ve genetik bulgular sınıflandirıldı.

Bulgular: Bir spontan abortus hariç tüm olgulara medikal abortus uygulandı $(\% 94,1)$. Yedi olguda genetik tanı konulamazken 13 olguda genetik bozukluk tanısı konuldu: iki trizomi 13, iki trizomi 18, bir (triploidi) 69, XXY, iki artrogripozis multipleks konjenita, bir osteogenesis imperfekta, bir letal multipl pterygium, bir SaldinoNoonan sendromu, bir teratojenik ilaç etkisi, bir perinatal letal hipofosfatazya ve bir Beckwith-Wiedemann sendromu. Azalmış fetal hareket en sık görülen bulgulardan biri idi. Akraba evliliği, oligohidramnios, annenin ilaç bağımlılı̆̆ sistemik anomaliler risk faktörü idi.

Sonuç: İskelet displazileri nadir görülen hastalıklardır. Klinisyenler perinatal dönem takiplerinde iskelet anomalilerine karşı dikkatli olmalıdır.

Anahtar sözcükler: Embriyonik ve fetal gelişim; fetal ölüm; fetal hareket; genetik hastalıklar; doğumsal.
Skeletal dysplasias, which are among the most common congenital skeletal diseases in childhood, can cause deformation and malformation on bone and cartilage tissues. ${ }^{[1,2]}$ Most of these diseases have genetic origin with a rate reported as 1/5,000 per birth. ${ }^{[3]}$ In this study, we aimed to report rates of skeletal abnormalities and their risk factors in light of information obtained in a fetal autopsy series. ${ }^{[4]}$

- Received: August 22, 2016 Accepted: October 28, 2016

- Correspondence: Mehmet Nuri Konya, MD. Kayadibi Mah., Atatürk Cad., Uğur Apt., No: 109, D: 3, 03200 Afyon, Turkey. Tel: +90 505 - 8296019 e-mail: nurikonya@hotmail.com

- This study was presented in 25th TOTBID National Congress, Antalya, Turkey as an oral presentation. 


\section{PATIENTS AND METHODS}

The study included 20 fetuses (11 males, 8 females and 1 ambiguous genitalia; mean age 19.3 \pm 4.0 weeks; range 16 to 32 week) who underwent either spontaneous or medical abortus and autopsy in Medical Faculty of Afyon Kocatepe University between January 2013 and March 2015. Our university hospital is a tertiary reference center which received 4,330 live births and 82 fetal abortus cases during that three-year time period.

Fetuses were systematically classified according to their age, gender, abortus week, family history, abortus type, upper or lower extremity abnormalities and other organ abnormalities. Radiographic and pathologic findings as well as genetic findings were also classified. The inclusion criteria were having phenotypical, radiological and skeletal abnormalities, weight over 500 gram and age over 16 weeks. Autopsies and chromosomal analyses from skin biopsies were performed for all cases. All fetuses were examined by an orthopedic surgeon, a medical genetics specialist, and a pathologist. The study protocol was approved by the Afyon Kocatepe University Ethics Committee (Ref no: 2015-10-270). A written informed consent was obtained from the families. The study was conducted in accordance with the principles of the Declaration of Helsinki.

\section{Statistical analysis}

Statistical analysis was conducted using IBM SPSS version 20.0 software (IBM Corp., Armonk, NY, USA). Descriptive statistics were given as percentages (\%) for categorical variables.

\section{RESULTS}

In prenatal medical history, 16 fetuses had hypokinesia, and 14 had family history of abortus. One mother had three abortuses previously due to 13-15 gene translocation. Three families had parental consanguinity, one family had a vanishing twin history, and one family had drug addiction history.

TABLE I

Family history of fetuses

\begin{tabular}{lcc}
\hline & Frequency & $\%$ \\
\hline No history & $6 / 20$ & 30.0 \\
Previous abortus & $6 / 20$ & 30.0 \\
Spondylocostal dysostosis & $1 / 20$ & 5.0 \\
Parental consanguinity & $5 / 20$ & 25.0 \\
Drug addiction & $1 / 20$ & 5.0 \\
Vanishing twin history & $1 / 20$ & 5.0 \\
\hline
\end{tabular}

All data from medical history of the cases and their families are demonstrated in Table I. Abortus weeks of the fetuses are demonstrated in Figure 1.

Except one spontaneous abortus, all fetuses were applied medical abortus (94.1\%). According to postmortem examination, seven cases did not have any genetic diagnosis whereas 13 were diagnosed with genetic disorders: Two trisomy 13, two trisomy 18, one 69,XXY, two arthrogryposis multiplex congenita (AMC), one osteogenesis imperfecta, one lethal multiple pterygium, one Saldino-Noonan syndrome, one teratogenic drug effect, one perinatal lethal hypophosphatasia (PLH), one Beckwith-Wiedemann syndrome (BWS) and one spondylocostal dysostosis type-1 (Table II). Additional abnormalities were also noted: microcephaly in two cases (10\%), nose abnormalities in eight cases (40\%), eye abnormalities in three cases (15\%), micrognathia in six cases (30\%) and intrauterine growth retardation in seven cases (35\%).

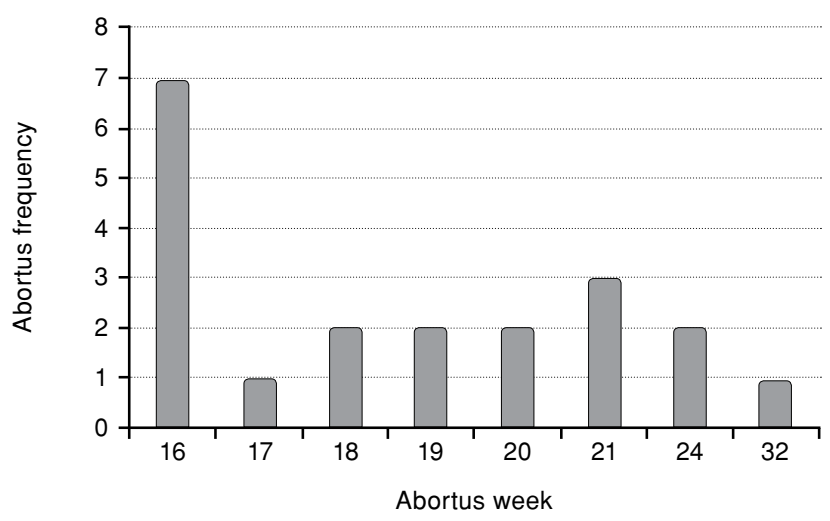

Figure 1. Abortus frequency distribution and week distribution.

TABLE II

Diagnosis of fetuses

\begin{tabular}{lcc}
\hline & Frequency & $\%$ \\
\hline No diagnosis & 7 & 35.0 \\
Trisomy 13 & 2 & 10.0 \\
Trisomy 18 & 2 & 10.0 \\
69, XXY & 1 & 5.0 \\
Arthrogryposis multiplex congenital & 2 & 10.0 \\
Osteogenesis imperfecta & 1 & 5.0 \\
Lethal multiple pterygium & 1 & 5.0 \\
Saldino-Noonan syndrome & 1 & 5.0 \\
Perinatal lethal hypophosphatasia & 1 & 5.0 \\
Beckwith-Wiedemann syndrome & 1 & 5.0 \\
Drug teratogenic effect & 1 & 5.0 \\
Total & 20 & 100.0 \\
\hline
\end{tabular}


TABLE III

Upper extremity findings

\begin{tabular}{lcc}
\hline & Frequency & $\%$ \\
\hline Shoulder & 13 & 65 \\
No findings & 6 & 30 \\
Short clavicle & 1 & 5 \\
Clavicle fracture & & \\
Elbow & 8 & 40 \\
No findings & 10 & 50 \\
Flexion contracture & 1 & 5 \\
Multiple pterygium & 1 & 5 \\
Bilateral elbow joint ankylosis & & \\
Wrist and hand & 5 & 25 \\
No diagnosis & 3 & 15 \\
Flexion contracture & 2 & 10 \\
Clenched hands & 1 & 5 \\
Camptodactyly & 1 & 5 \\
Multiple fractures & 1 & 5 \\
Multiple pterygium & 1 & 5 \\
Syndactyly & 1 & 5 \\
Flexion contracture + syndactyly & 1 & 5 \\
Clenched hand + syndactyly & 1 & 5 \\
Brachysyndactyly + polydactyly & 1 & 5 \\
Spiky bones & 1 & 5 \\
Thump agenesis and $3^{\text {rd }}$ finger fusion & 1 & 5 \\
Single transverse line & 1 & \\
\hline & & 5 \\
Total & 1 & 5 \\
\hline
\end{tabular}

Orthopedic findings were divided into two groups according to location as upper or lower extremity. Upper extremity findings were six short clavicles $(30 \%)$, one fracture of the clavicle $(5.0 \%)$, ten flexion

TABLE IV

Lower extremity findings

\begin{tabular}{lcc}
\hline & Frequency & $\%$ \\
\hline Hip & 14 & 70 \\
No diagnosis & 3 & 15 \\
Narrow pelvis & 1 & 5 \\
Flexion contracture, narrow pelvis & 1 & 5 \\
Proximal femur fracture & 1 & 5 \\
Right femur amelia, left short femur & 20 & 100 \\
Total & & \\
Foot and ankle & 5 & 25 \\
No diagnosis & 11 & 55 \\
Bilateral talipes equinovarus & 1 & 5 \\
Multiple pterygium & 2 & 10 \\
Flexion contracture & 1 & 5 \\
Ankle joint fusion & 20 & 100 \\
Total & & \\
\hline
\end{tabular}

contracture of the elbow joints (50\%), one multiple pterygium (5\%), one elbow ankylosis (5\%), two clenched hand deformities $(10 \%)$, one multiple bone fractures $(5 \%)$, one syndactyly $(5 \%)$, one polydactyly with brachysyndactyly (5\%), one three-finger fusion with thumb agenesis (5\%), and one bone spurs $(5 \%)$ (Table III).

Lower extremity findings were six flexion contractures (30\%), one proximal femur fracture (5\%), one lower extremity amelia and contralateral short femur $(5 \%)$, three narrow pelvises $(15 \%)$, one tibial bowing (5\%), and nine talipes equinovarus deformity $(45 \%)$ (Table IV). Two cases had scoliosis $(10 \%)$ and the other two had vertebral fusion abnormalities $(10 \%)$ (Table V). In the current study, familial history of previous abortus and parental consanguinity were identified as the main risk factors for skeletal abnormalities. The most common skeletal deformities of the lower extremity were talipes equinovarus and rocker bottom foot. The most common deformities of the upper extremity were flexion contractures especially in the elbow joint and finger formation abnormalities.

\section{DISCUSSION}

Skeletal dysplasias are rarely seen congenital disorders and affect nearly $1 / 5,000$ births. ${ }^{[3]}$ In this study, we investigated the most common skeletal findings, genetic origins and risk factors of skeletal dysplasias.

All fetuses were classified according to extremity findings, non-orthopedic abnormalities and internal system disorders. Some of our patients' families had a genetic history. The most common orthopedic findings in upper extremities were hand abnormalities. Syndactyly, polysyndactyly, and clenched hand deformities were the most repetitive disorders.

Edwards or trisomy 18 syndrome is a chromosomal disorder characterized by the presence of an extra chromosome 18. The first reported infants were described in $1960 .{ }^{[5]}$ The prevalence of live birth for trisomy 18 has been reported to range from

\section{TABLE V}

Vertebral findings

\begin{tabular}{lcc}
\hline Vertebra & Frequency & $\%$ \\
\hline No findings & 14 & 70.0 \\
Scoliosis & 2 & 10.0 \\
Vertebral fusion & 2 & 10.0 \\
Platyspondyly & 2 & 10.0 \\
Total & 20 & 100.0 \\
\hline
\end{tabular}




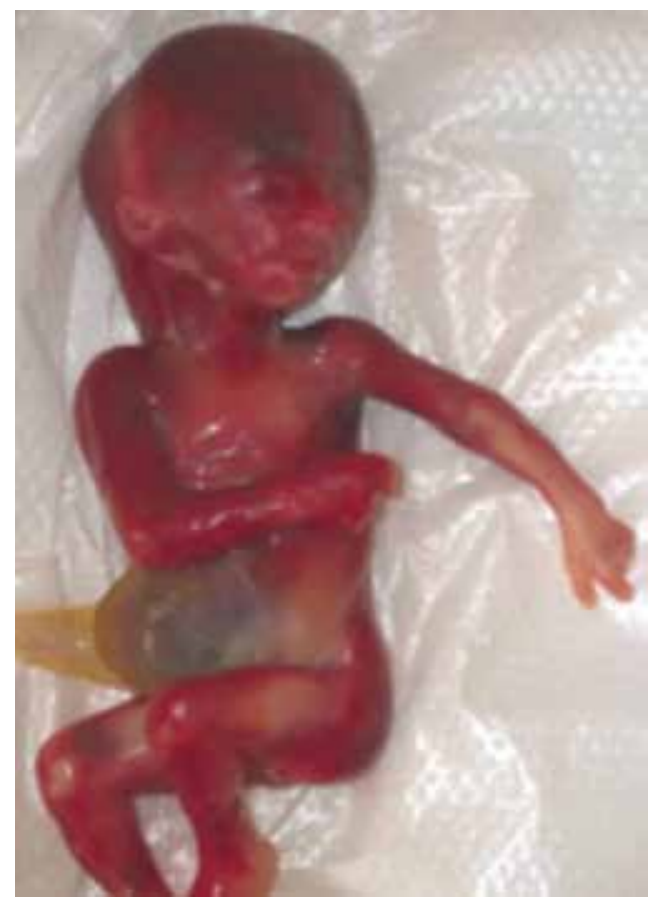

Figure 2. Patient with Edwards syndrome: flexion contracture of right elbow and bilateral knees. Right gand camptodactyly, omphalocele.

$1 / 3,600$ to $1 / 10,000 .{ }^{[6]}$ In our series, two fetuses were diagnosed as trisomy 18 as the major findings were intra-uterine growth retardation, congenital heart defect, cleft lip/palate, micrognathia, rocker bottom feet, ulnar or radial deviation of hand, hypoplastic or absent thumb, single transvers crease, syndactyly of second and third toes. ${ }^{[5]}$ Our cases had some additional findings such as omphalocele, exophthalmos and hydrocephaly (Figure 2).

Trisomy 13 was first described in 1960 by Patau et al. ${ }^{[7]}$ with discovery of the extra chromosome 13 . The major findings were described as eyes defect, nose and lip abnormalities, polydactyly, simian crease, flexion contractures of the fingers with or without overlapping and camptodactyly. Our series included two cases of trisomy 13. The extra findings that were observed in these two fetuses were one fetus with small thorax and the other with multiple joint contractures (Figure 3).

Triploidy is a complex disorder, which affects $2 \%$ of the cases with chromosomal abnormalities. Triploid infants survive with intrauterine growth retardation, asymmetric growth deficiency, syndactyly and ambiguous genitalia. ${ }^{[8]}$ In our series, one 69,XXY fetus was diagnosed presenting with small thorax, small clavicle as well as clenched hands deformity and vertebral fusion abnormalities (Figure 4).

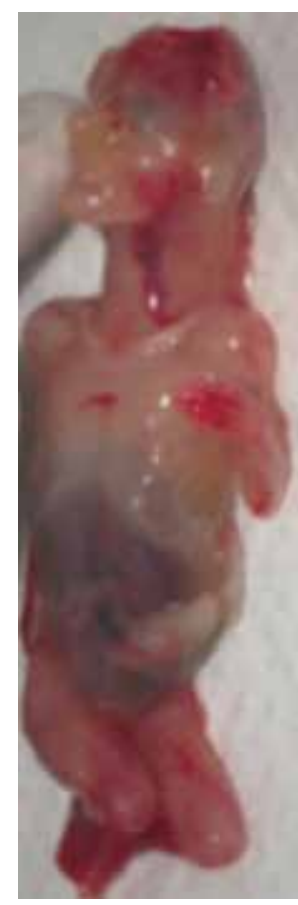

Figure 3. Patient with trisomy 13: flexion contracture of right elbow and bilateral knees. Right hand syndactyly and bilateral rocker bottom feet.

One patient was observed with Saldino-Noonan syndrome, ${ }^{[9]}$ which can also be named as short-rib thoracic dysplasia with or without polydactyly, which refers to a group of autosomal recessive skeletal ciliopathies characterized by a constricted thoracic cage, short thorax, short ribs, shortened tubular bones, polydactyly and hydrops fetalis. Our case had similar clinical synopsis with left hemihypertrophy (Figure 5).
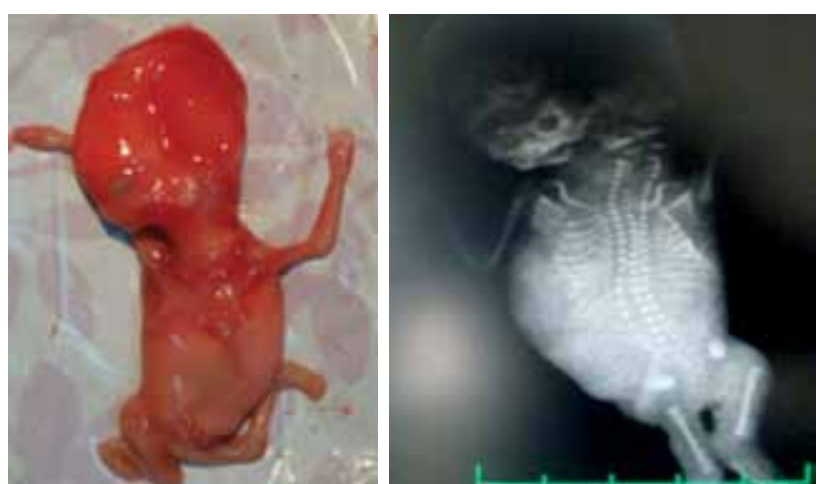

Figure 4. Patient with triploidy: scalp abnormalities, cleft vertebrae, rib abnormalities and rocker bottom feet, short femur. 


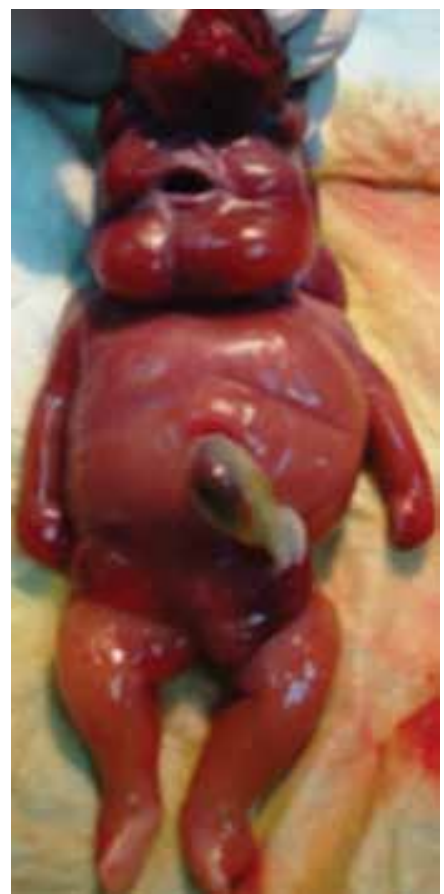

Figure 5. Patient with SaldinoNoonan hydrops fetalis, short rib, short thorax, synpolydactyly.

Two fetuses were diagnosed with $\mathrm{AMC}{ }^{[10]}$ which is described as congenital joint contractures in two or more areas of the body including gryposis of whole extremity and joints. Every joint in the body can have typical signs and symptoms like internal rotation of the shoulder, volar and ulnar deviation of the wrist, fingers in fixed flexion and thumb in palm deformity of the hand, flexed, abducted, externally rotated, and frequently dislocated hip, extension and pronation in the elbows, and talipes equinovarus or vertical talus deformity of the feet. Two of the fetuses examined during this study had all signs and findings of AMC during physical examinations (Figure 6). In a review of 15,000 newborns, Karapinar et al. ${ }^{[11]}$ reported the most common foot deformity as talipes equinovarus. Our results supported the findings of their study.

One fetus had lethal multiple pterygium syndrome, ${ }^{[12]}$ which has been reported as characterized by intrauterine growth restriction and pterygia in multiple areas (chin to sternum, cervical, axillary, humeroulnar, crural, popliteal, and the ankles) and flexion contractures giving rise to severe arthrogryposis. The fetus in our series was diagnosed with intrauterine growth restriction and multiple pterygium areas (cervical, axillary, humeroulnar, popliteal and ankles) (Figure 7).

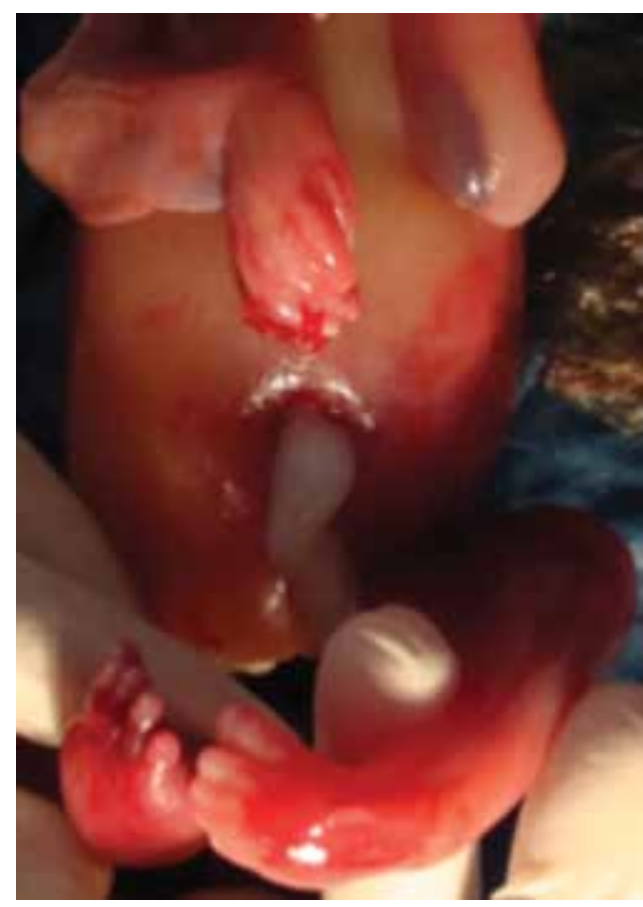

Figure 6. Patient with arthrogryposis multiplex congenita upper and lower extremity joint contracture.

Osteogenesis imperfecta ${ }^{[13]}$ is caused by sporadic mutations of an autosomal dominant gene (COL 1A1 or COL 1A2). It causes weak bones, which can be

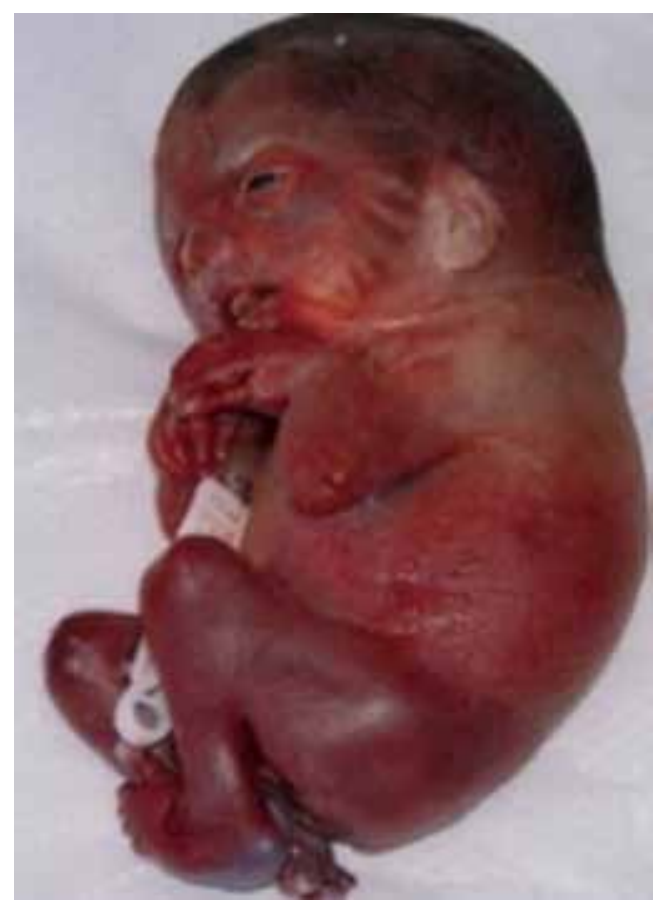

Figure 7. Patient with lethal multiple pterygium, whole joint had pterygium and flexion contracture. 
broken easily. One fetus in our series had very brittle bones prone to fracture and multiple fractures were detected on X-ray scans thus, the case was identified as osteogenesis imperfecta. Besides, the fetus also had exophthalmos and frontal bossing in physical examination (Figure 8).

One fetus diagnosed as $\mathrm{PLH}^{[14]}$ had generalized defective mineralization of the bones including the skull and multiple fractures due to low activity of serum alkaline phosphatase enzyme. In parental history, consanguineous marriage and one more baby with diagnosed PLH were noted (Figure 9).

One fetus was diagnosed with BWS, ${ }^{[15]}$ which includes macrosomia, omphalocel, organomegaly and platyspondyly, and is a special skeletal dysplasia in vertebra. In addition, the fetus had also an abnormal asymmetry between the left and right sides of the body characterized with one part of the body growing faster than normal. Children with BWS and hemihypertrophy can have an isolated asymmetry of one body part, or they can have a difference affecting the whole one side of the body. On the other hand, individuals who do not have BWS can also have hemihypertrophy.

Fetal movements are generally described body movements, isolated finger movements, breathing, isolated head-neck movements, stretching and rolling. Although fluctuating movements start between $8^{\text {th }}$ to $12^{\text {th }}$ weeks of gestation, strong movements are generally recognized between $13^{\text {th }}$ to $16^{\text {th }}$ weeks and movements in extremities and body at about $17^{\text {th }}$ to $18^{\text {th }}$ weeks. ${ }^{[16]}$ All these movements are completed at the $15^{\text {th }}$ gestational week but mothers can feel these movements during $16^{\text {th }}$ to $18^{\text {th }}$ weeks. Hayat et al. ${ }^{[17]}$ reported that the frequency of the fetal
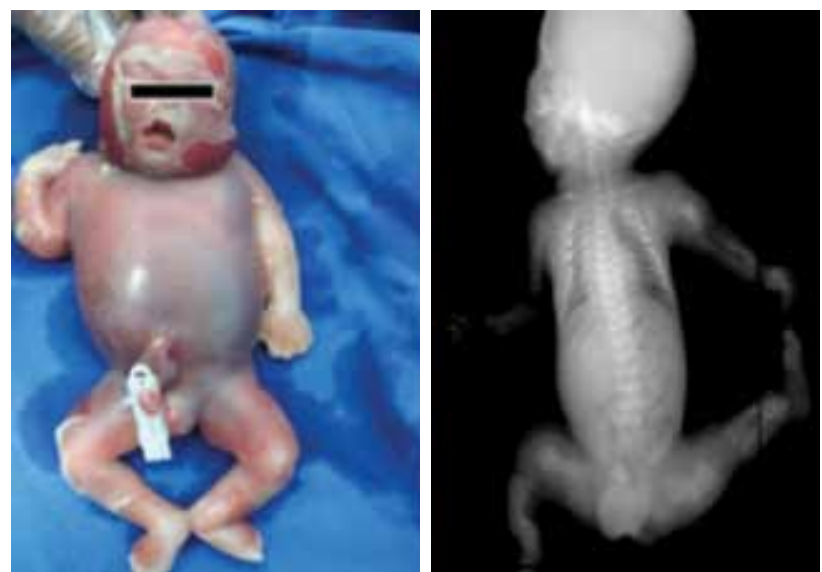

Figure 8. Patient with osteogenesis imperfecta hydrops fetalis and multiple bone fractures. movements was generally much more than the third trimester ( $36^{\text {th }}$ week) and if fetus has got decreased central nervous system maturity, fetal movements may hypokinesia or akinesia.

In our study, all mothers were asked about their feeling of the movements and 16 of the mothers verified being aware of decreased fetal movements. Especially the mothers of the fetuses diagnosed having joint contractures and AMC reported a strong feeling of fetal hypokinesia or fetal akinesia. Therefore, feeling of a pregnant mother about decreasing fetal movements can be an alerting sign for the doctors and may inform us about the possible skeletal abnormalities of the fetus. Fetal movements can be used as one of the determinants for evaluating fetal health status as well as musculoskeletal and neurobehavioral development. ${ }^{[18]}$ In our study, intrauterine fetal death was described via reduction in fetal movements for 24 hours in up to $50 \%$ of cases. Reduced fetal movement should be one of the major reasons for application to a clinician.

Skeletal dysplasia is an umbrella term, including 436 conditions in 42 groups. To avoid reporting same conditions with different terms, international nosology and classification of constitutional disorders of bone ${ }^{[19]}$ has been used. In our study, we also classified our patients according to this classification. In nosology classification, syndromes and trisomies are not included. According to our results, trisomy 13 , trisomy 18 , and $69, \mathrm{XXY}$ are chromosomal abnormalities and AMC, LMP and BWS are syndromes; so they were not included in nosology classification. Osteogenesis imperfecta was in $25^{\text {th }}$ group, osteogenesis imperfecta and decreased bone density group, Saldino-Noonan was in nineth short-rib dysplasias (with or without polydactyly)
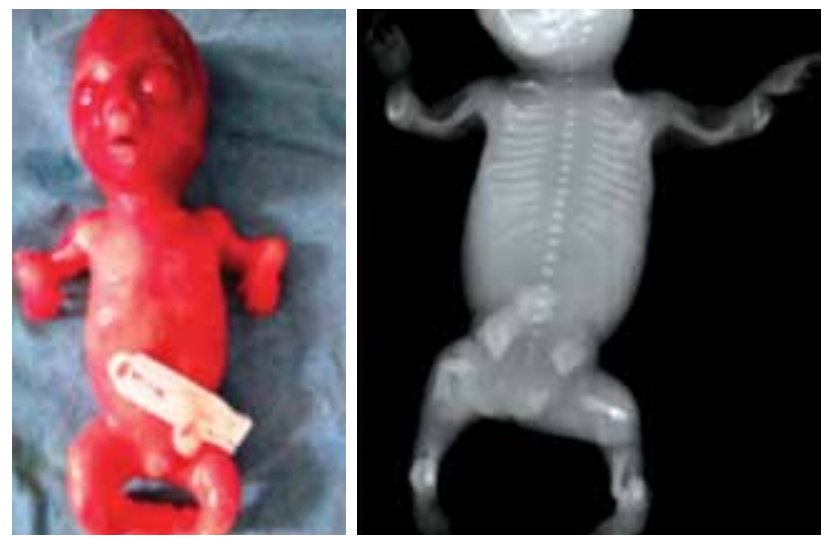

Figure 9. Patient with perinatal lethal hypophosphatasia, decreased bone mineral density, especially in scalp, multiple fractures and deformities in extremities. 
group, and PLH was in $26^{\text {th }}$ abnormal mineralization group.

A limitation of our study is its small sample size of 20 fetuses, which includes wide variety of disease groups. The ratios detected in this study may change with larger sample sizes. Therefore, further studies with larger sample sizes are required to investigate skeletal dysplasias in perinatal period.

In conclusion, parental history of consanguineous marriage, fetal presentation abnormalities, oligohydramnios, drug addiction of the mother, teratogenic exposure and other associated systemic abnormalities (cardiac and gastrointestinal system abnormalities) may be recognized as risk factors for skeletal dysplasias. Decreased fetal movements during perinatal period can be a significant finding for skeletal dysplasia and should be evaluated carefully during follow-ups.

\section{Declaration of conflicting interests}

The authors declared no conflicts of interest with respect to the authorship and/or publication of this article.

\section{Funding}

The authors received no financial support for the research and/or authorship of this article.

\section{REFERENCES}

1. Botto LD, Moore CA, Khoury MJ, Erickson JD. Neural-tube defects. N Engl J Med. 1999;341:1509-19.

2. Atalar H, Turanlı S, Atik OŞ, Kaptan AY, Ezgü FS. Situs inversus of the fibula: medialized fibula. [Article in Turkish] Eklem Hastalik Cerrahisi 2015;26:60-2.

3. Orioli IM, Castilla EE, Barbosa-Neto JG. The birth prevalence rates for the skeletal dysplasias. J Med Genet 1986;23:328-32.

4. Atik OŞ. Are all case reports worth publishing? Eklem Hastalik Cerrahisi 2016;27:61.

5. Cereda A, Carey JC. The trisomy 18 syndrome. Orphanet J Rare Dis 2012;7:81.

6. Rasmussen SA, Wong LY, Yang Q, May KM, Friedman JM.
Population-based analyses of mortality in trisomy 13 and trisomy 18. Pediatrics 2003;111:777-84.

7. Patau K, Smith DW, Therman E, Inhorn SL, Wagner HP. Multiple congenital anomaly caused by an extra autosome. Lancet 1960;1:790-3.

8. Graham JM Jr, Hoehn H, Lin MS, Smith DW. Diploidtriploid mixoploidy: clinical and cytogenetic aspects. Pediatrics 1981;68:23-8.

9. Saldino RM, Noonan CD. Severe thoracic dystrophy with striking micromelia, abnormal osseous development, including the spine, and multiple visceral anomalies. Am J Roentgenol Radium Ther Nucl Med 1972;114:257-63.

10. Ayadi K, Trigui M, Abid A, Cheniour A, Zribi M, Keskes H. Arthrogryposis: clinical manifestations and management. Arch Pediatr 2015;22:830-9. [Abstract]

11. Karapinar L, Öztürk H, Sürenkök F. Evaluation of results of an orthopaedic screening program of 15.000 newborns. Eklem Hastalik Cerrahisi 2001;12:139-43.

12. Chen CP. Prenatal diagnosis and genetic analysis of fetal akinesia deformation sequence and multiple pterygium syndrome associated with neuromuscular junction disorders: a review. Taiwan J Obstet Gynecol 2012;51:12-7.

13. Arslan H. İntrauterine fetal femoral fracture (Case Report). Eklem Hastalik Cerrahisi 2011;12:203-4.

14. Gül O, Atik OS, Erdoğan D, Göktaş G, Elmas C. Transmission and scanning electron microscopy confirm that bone microstructure is similar in osteopenic and osteoporotic patients. Eklem Hastalik Cerrahisi 2013;24:126-32.

15. Le Vaillant C, Beneteau C, Chan-Leconte N, David A, Riteau AS. Beckwith-Wiedemann syndrome: What do you search in prenatal diagnosis? About 14 cases. Gynecol Obstet Fertil 2015;43:705-11. [Abstract]

16. de Vries JI, Fong BF. Normal fetal motility: an overview. Ultrasound Obstet Gynecol 2006;27:701-11.

17. Hayat TT, Nihat A, Martinez-Biarge M, McGuinness A, Allsop JM, Hajnal JV, et al. Optimization and initial experience of a multisection balanced steady-state free precession cine sequence for the assessment of fetal behavior in utero. AJNR Am J Neuroradiol 2011;32:331-8.

18. Nowlan NC. Biomechanics of foetal movement. Eur Cell Mater 2015;29:1-21.

19. Bonafe L, Cormier-Daire V, Hall C, Lachman R, Mortier G, Mundlos S, et al. Nosology and classification of genetic skeletal disorders: 2015 revision. Am J Med Genet A. 2015;167:2869-92. 